\title{
Mid-Pleistocene thin-skinned glaciotectonic thrusting of the Aberdeen Ground Formation, Central Graben region, central North Sea
}

\author{
David P. Vaughan-Hirsch ${ }^{1 *}$ and Emrys Phillips ${ }^{2}$ \\ 1. Fugro Survey Limited, Survey House, Denmore Road, Bridge of Don, Aberdeen \\ AB23 8JW, UK (d.vaughan-hirsch@fugro.com) \\ 2. British Geological Survey, Murchison House, West Mains Road, Edinburgh EH9 \\ 3LA, UK \\ * Corresponding author
}

\begin{abstract}
This paper presents the results of a high-resolution 2D seismic survey of Mid-Pleistocene glaciogenic sediments in the Central Graben region of the central North Sea. The survey has revealed that these sediments, which were originally interpreted as possessing a simple layercake stratigraphy, have in fact undergone major glaciotectonic thrusting and folding associated with the repeated southerly advance of an ice sheet across the region during the Mid-Pleistocene. The total observed length of the thrust-stacked section is approximately 5 to $6 \mathrm{~km}$, comprising a series of discrete thrust slices, which range in length from $<300 \mathrm{~m}$ to $>$ $700 \mathrm{~m}$. The basal detachment of the thrust complex occurs at a depth of c. $220 \mathrm{~m}$ below sea bed within the upper Aberdeen Ground Formation. The ice-proximal limit of thrusting is marked by a large depression (>100 m deep, >1600 m wide) infilled by a sequence comprising at its base acoustically chaotic deposits, overlain by a well-bedded unit, passing upwards into tectonically deformed sediments. A thin-skinned glacitectonic model involving proglacial to ice-marginal glacitectonic thrusting followed by post-tectonic deposition is proposed. Initial ice advance led to the over-pressurising of groundwater within a laterally extensive sand sheet in the upper Aberdeen Ground Formation, promoting the formation of a major décollement surface at the base of the developing thrust stack. Detachment and transport of the thrusted sediments led to the contemporaneous formation of a "glacitectonic hollow" beneath the ice margin. Dewatering of the basal décollement, possibly due to water escaping from the thrusts which propagated upwards through the Aberdeen Ground, led to the cessation of forward propagation of the leading-edge of the thrust stack accompanied by extensive shortening and deformation at its ice-proximal end. Subsequent retreat of the ice exposed the tectonic hollow which became infilled with glacial outwash. This glacifluvial sequence was itself deformed during later readvance of the ice from the north. The proposed model provides clear evidence that Mid-Pleistocene ice sheet dynamics within the Central Graben of the North Sea was far more complex than previously thought.
\end{abstract}




\section{Introduction}

Glaciogenic sedimentary sequences frequently show evidence of having undergone significant glacitectonic disturbance which accompanied the shortening of the sediment pile (van Gijssel, 1987; van der Wateren, 1986; van der Wateren, et al., 2000; Phillips et al., 2002; Aber and Ber, 2007; Phillips et al., 2008). The detailed analysis and interpretation of the structural features (folds, faults, foliations) developed within subglacially (Berthelsen, 1979; Ben and Evans, 1996; Boulton et al., 1996; Hart and Rose, 2001; Phillips et al., 2007; Lee and Phillips, 2008) and proglacially (Berthelsen, 1979; Hart, 1990; Pedersen, 1993; Boulton et al., 1999; Phillips et al., 2002; Benediktsson et al., 2008; Phillips et al., 2008) deformed sediments has been providing important information on the character of these glacier-induced deformation events. Ice-marginal to proglacial deformation typically involves folding and thrusting, and is therefore comparable to foreland fold-and-thrust belts developed in response to crustal shortening and mountain building, albeit affecting a smaller (sub-km) lateral scale and shallower (typically $<100 \mathrm{~m}$ ) vertical extent. This similarity has led to the direct application of a thin-skinned thrust tectonic model as an aid to our understanding of ice marginally deformed glacigenic sequences (Berthelsen, 1979; Croot, 1987; van Gijssel, 1987; Pedersen, 1987; Banham, 1988; Aber et al., 1989; Bennett, 2001; Pedersen, 2000; Bakker, 2004; Andersen et al., 2005). This style of deformation has been reported from a range of previously glaciated areas, including North America (e.g. Moran et al. 1980; Bluemle and Clayton, 1984), northern Europe (e.g. van der Wateren, 1986; Huuse and Lykke Andersen, 2000; Pedersen, 2002, 2005) and the United Kingdom (e.g. Harris et al., 1995, 1997; Thomas and Chiverrell, 2007; Phillips and Merritt, 2008; Phillips et al., 2008; Burke et al., 2009) and the Republic of Ireland (e.g. Hiemstra et al., 2007), as well as within the marine environment, such as throughout the Polar north Atlantic (e.g. Ottesen et al. 2005, Andreassen et al. 2009), Barents Sea (e.g. Andreassen et al., 2004; Rüther et al., 2013), and North Sea (e.g. Huuse et al., 2000a, b; Buckley, 2012a, b; Krzywiec et al., 2003; Cotterill et al., this volume).

The overall indication from both terrestrial and marine-based studies is that this style of glaciotectonic deformation may be a relatively common feature within glaciated regions (Jakobsen, 1996). Importantly deformation can occur both during (syn) or after (post) deposition (Baroni and Fasano, 2006) with the resulting glacigenic sequence recording the complex interplay between sedimentation and thin-skinned glacitectonism. The high degree of local variability in the style of both sedimentation and deformation observed in some ice marginal sequences has been interpreted in terms of multiple stages of glacial advance and retreat, thereby providing a direct record of former ice sheet dynamics (e.g. van der Wateren, 1986, 1995; Croot, 1988; Aber et al., 1989; Ben and Evans, 1993; Harris et al., 1997; Phillips et al., 2002; Hiemstra et al., 2005). However, the factors controlling the development of such large-scale thrust systems and in particular the propagation of the associated relatively deepseated (up to several hundred metres) décollements during deformation at the margins of glaciers and ice sheets remain poorly understood. Understanding how these major detachment surfaces are initiated is fundamental to our understanding the evolution of large-scale glacitectonic thrust complexes and their relationship to ice sheet dynamics. 
This paper provides evidence for large-scale thrusting and folding of the midPleistocene glaciogenic sediments of the Aberdeen Ground Formation present within the Central Graben region of the central North Sea (Block 30/8, Fig. 1a). Although these sediments were originally interpreted as possessing a simple layer-cake stratigraphy (Stoker et al., 1985; Cameron et al., 1987; Gatliff et al., 1994), detailed analysis of 2D seismic data has revealed that this sedimentary sequence has undergone major glaciotectonic disruption during a Mid-Pleistocene glaciation. The data is further used to erect a thin-skinned glacitectonic model involving proglacial to ice-marginal glacitectonic thrusting followed by post-tectonic deposition to explain the evolution of the this part of the Central Graben. The factors controlling the location and propagation of the major décollement surface deep within the Aberdeen Ground Formation which forms the base of the thrust complex, are also examined. The proposed thin-skinned model also provides clear evidence that ice sheet dynamics within the Central Graben of the North Sea during the Mid-Pleistocene was far more complex than previously thought.

\section{Regional Quaternary Geology and location of study area}

The study area lies within UKCS Quad 30 which is situated north of $56^{\circ} \mathrm{N}$ within the Central Graben of the central North Sea (Fig. 1a) and within the area covered by the British Geological Survey’s (BGS) 'Fisher’ (56-02) 1:250,000 scale Quaternary geology map sheet (Fyfe, 1986). The Quaternary geology of this part of the central North Sea is characterised by a complex sedimentary sequence laid down during several glacial and interglacial episodes (Sejrup et al., 1987), with fully glacial conditions becoming apparent in the Mid-Pleistocene (Gatliff et al., 1994). An early attempt to construct a formal lithostratigraphy for the central North Sea by Holmes (1977) was subsequently refined by the work of Stoker et al. (1985) (Table 1). However, the sedimentary architecture of the central North Sea is known to be complex, and the present study area occurs within a zone covered by two adjacent, but not fully-integrated lithostratigraphic sequences (Gatliff et al., 1994; Cameron et al., 1987). These two lithostratigraphic systems have been applied exclusively to the areas north and south of what may be described as a regional-scale disconformity located at approximately $56^{\circ} \mathrm{N}$, east of $0^{\circ}$ (Stoker et al. 2011). South of this latitude, Early Pleistocene sediments are represented by the Deltaic division of Cameron et al. $(1987,1992)$ and were deposited by a large prograding fluvial-delta system which originated in Denmark and the Netherlands. In this southern region, continued deltaic and delta-top sedimentation was later followed by marine transgression and the formation of a shallow sea during the 'Cromerian Complex' (West, 1980). To the north of $56^{\circ}$, the Mid-Pleistocene sediments comprises pro-deltaic sands and muds (Stoker and Bent, 1985). The mud-rich upper part of the sequence in this northern area has been assigned to the Aberdeen Ground Formation (Table 1) which includes pebbly and sandy sediments containing cold-water foraminifera (Gatliff et al., 1994). The Aberdeen Ground Formation has previously been interpreted as having been deposited in subglacial to proglacial environments of a grounded, tidewater glacier (Stoker and Bent, 1985, 1987; Sejrup et al., 1987), and as such represent the earliest evidence for glacial conditions within the central North Sea (Stoker and Bent, 1985). 
The Aberdeen Ground Formation is typically overlain by the silt, clay and silty clay of the Ling Bank Formation (Gatliff et al., 1994). Previous workers have recognised several units within the Ling Bank Formation (Table 1) which is largely thought to be Holsteinian/Hoxnian (Marine Isotope Stage (MIS) 11) in age (Stoker et al., 1985; Knudsen and Sejrup, 2008). However, the base of Ling Bank Formation is less well-defined and may include interglacial sediments of 'Cromerian Complex' age (Gatliff et al., 1994). To the north of $56^{\circ}$, the Ling Bank Formation is overlain by interbedded fine-grained sands and muds of the Fisher Formation (Table 1). The Fisher Formation is interpreted as being glaciomarine in origin and is likely to be Saalian in age (Stoker et al., 1985; Knudsen and Sejrup, 1993).

The Forth Formation (Table 1) occurs at the top of the Mid-Pleistocene sequence to the north of $56^{\circ}$ where it crops out extensively at the seabed. The formation comprises marine and glaciomarine sands and muds which form both a regional-scale blanket cover, as well as infilling locally developed channels; the latter being interpreted as having formed adjacent to the margin of a major ice sheet (Wingfield, 1990; Ehlers et al., 1991). The Forth Formation is thought to have been laid down during the Last Glacial Maximum of the Weichselian (Devensian) glaciation (Stoker et al., 1985; Ehlers et al., 1991; Sejrup et al., 2008) during a period when the British and Irish and Scandinavian ice sheets reached their maximum extents in the central North Sea (Carr et al., 2006).

\section{Methodology}

This paper utilises the results of a marine high-resolution 2D seismic survey of part of the Central Graben region, central North Sea (Fig. 1a), carried out aboard the Gardline survey ship M.V. Ocean Reliance. High Resolution Seismic (HRS) data were acquired using a 4 x 40 cubic inch sleeve gun array and a 1200 m, 96 channel Sercel SEAL 428 streamer. A record length of 2.2 seconds was obtained at a sample rate of $1 \mathrm{~m} / \mathrm{s}$ and shot point interval of $6.25 \mathrm{~m}$. Positioning was controlled by differential Global Positioning System (GPS) to within an accuracy of $\pm 3 \mathrm{~m}$, and logged in real-time by a Voyager5 survey computer. The HRS equipment specified was expected to achieve a vertical resolution of $\sim 4 \mathrm{~m}$. A total of 345 line-kilometres of data were collected (Fig. 1b), with 28 primary lines oriented at $154^{\circ} / 334^{\circ}$, and 59 perpendicular cross-lines oriented at $064^{\circ} / 244^{\circ}$. The survey grid applied a line spacing of $100 \mathrm{~m}$, and achieved a total coverage of $5.78 \mathrm{~km}$ x $2.68 \mathrm{~km}$. Additionally, three longer (approximately $10 \mathrm{~km}$ ) tie lines were run oblique to the primary lines in order to provide wider context. The orientation and layout of the survey grid and the key seismic lines (red lines) analysed during the present study are shown on Fig. $1 \mathrm{~b}$.

Industry standard seismic processing was carried out onshore, with resultant SEGY data files loaded into IHS Kingdom for interpretation and analysis. All seismic data are presented in zero-phase and normal polarity, where a positive reflection coefficient produces a positive amplitude value which is displayed as a black reflector on the resulting seismic profile (Figs. 2, 3 and 4). Conversely, a negative impedance contrast produces a negative amplitude value which is displayed as a red reflector. Interpretation of the shallow sequence and horizon picking is principally based upon 2D HRS data, with a specific focus upon 
acoustic character and apparent structure. Horizons defining both the basal detachment and the upper bounding surface of the thin-skinned tectonism were digitised across the study area and gridded to create depth-converted surfaces (Fig. 5). For this purpose, a velocity profile of $1495 \mathrm{~m} / \mathrm{s}$ was utilised for the water column, based upon 3 velocity profile dips. A static velocity of $1650 \mathrm{~m} / \mathrm{s}$ is used to convert two-way travel time (TWTT) in milliseconds (ms), to depth in metres below seabed (m BSB). Although no suitable local borehole or well data was available to relate to the 2D HRS dataset, a variety of regionally-appropriate commercial site survey reports and published research (Buckley, 2012) were used to aid interpretation of the lithostratigraphy. Structural measurements were taken from each of the thrust-slices, with apparent dip taken from the long profile centreline, and appropriate cross-lines. Values of inferred dip were calculated using the geometrical functions present within Geocalculator 4.9.6 (Holcombe, 2012) with resultant data presented graphically on a series of rose diagrams and a lower-hemisphere stereographic projection (Fig. 6).

\section{Interpretation of 2D HRS seismic data}

The Aberdeen Ground Formation is the oldest lithostratigraphic unit recognised on the seismic profiles within the study area (Unit 1 on Figs. 2 to 5). The base of formation can be traced across the entire survey area and is marked by a high-amplitude, very gently NWdipping $\left(<1^{\circ}\right)$ reflector at approximately $824 \mathrm{~ms}(600 \mathrm{mBSB})$. In the commercial site survey reports, this lithostratigraphical boundary is commonly referred to as the 'stratigraphic nearbase Quaternary', although the true base Gelasian (not observed in this survey) is likely to be significantly deeper (Buckley, 2012a). The Aberdeen Ground Formation is characterised by subhorizontal, laterally continuous internal reflectors which represent bedding within this predominantly clay-rich unit. Acoustically transparent horizontal horizons within the formation are thought to represent laterally extensive sheet sands. The most obvious of these sand sheets (grey layer on Figs. 2, 3 and 4) is approximately $8 \mathrm{~m}$ thick with its upper and lower surfaces occurring at $354 \mathrm{~ms}$ TWTT (212 mBSB) and $362 \mathrm{~ms}$ TWTT (220 mBSB), respectively (Figs. 2 and 3). Immediately above this prominent sand horizon the Aberdeen Ground Formation is deformed and disrupted by a series of gently to moderately, N-dipping faults (individual faults approximately $0.5-1 \mathrm{~km}$ in length) which propagate upwards from a subhorizontal detachment located at c. $354 \mathrm{~ms}$ TWTT (212 mBSB) (Fig. 2). This detachment forms the basal décollement to the glacitectonised sequence and occurs at, or very close to, the top of a prominent sand sheet (grey layer on Figs. 2, 3 and 4). The majority of the northerly dipping faults terminate at c. 246 ms TWTT depth (125 m BSB; Figs. 2 and 3) and display a reverse, southerly directed sense of movement, indicating that they represent a series of southward propagating thrusts (see Fig. 2). This thrusting can be traced laterally for some 4 to $6 \mathrm{~km}$ and affects an approximately 95 to $100 \mathrm{~m}$ thick unit within the upper part of the Aberdeen Ground Formation (see Figs. 2 and 3). Bedding within the hanging-walls of a number of these thrusts is deformed by large-scale, southerly verging anticlines/monoclines and small-scale southerly dipping back-thrusts (Figs. 2 and 3).

The sequence above the thrusted zone is acoustically distinct from the structurally underlying Aberdeen Ground Formation (compare Units 1 and 2 on Figs. 2 and 3). This 
acoustically more chaotic unit locally contains poorly preserved channel-like features and possesses short, internal reflectors suggesting that it is relatively poorly bedded (Unit 2 on Figs. 2 and 3). The undulating boundary between units 1 and 2 is clearly folded and offset by the thrusts. However, the relative intensity of this deformation decrease upwards through Unit 2 with these poorly bedded sediments apparently infilling the undulating upper surface of the folded and thrusted Aberdeen Ground Formation sequence (see Fig. 3).

Towards the north of the survey area, Units 1 and 2 are incised by a c. 2 to $4 \mathrm{~km}$ wide incised depression which clearly truncates the thrusted and folded unit within the Aberdeen Ground Formation (Fig. 2). Importantly, to the north of this depression the Aberdeen Ground Formation is undeformed. Examination of the adjacent seismic lines demonstrate that the depression forms a trench-like feature, the long-axis of which trends approximately NE-SW and extends beyond the limit of the present study area. Furthermore, this incised feature clearly cuts downwards into the underlying undeformed Aberdeen Ground Formation reaching a maximum depth of $480 \mathrm{~ms}$ TWTT (317 mBSB). Seismic evidence indicates that the depression comprises several generations of fill, the lowermost of which is acoustically chaotic unit (up to c. $130 \mathrm{~m}$ thick) with no discernible internal structure (Unit 3 on Figs. 2 and 4a). Along its southern flank, the boundary between Unit 3 and the northernmost limit of the folded and thrusted Aberdeen Ground Formation is deformed/modified by a number of gently to moderately, N/NW-dipping ( $>25^{\circ}$ ) normal faults (Fig. 3). In contrast the northern margin of the depression is marked by a "stepped" or undulating erosion surface at the base of Unit 3 (Fig. 2). The top of Unit 3 in the centre of the depression occurs at approximately $320 \mathrm{~ms}$ TWTT (185 m BSB) (Fig. 4a).

Overlying Unit 3 is a well-bedded unit characterised by largely coherent, laterally continuous internal reflectors (Unit 4 on Figs. 2 and 4a). Unlike Unit 3 which is solely confined to the depression infill sequence, Unit 4 (c. 30-40 m thick) is laterally more extensive and can be traced for more than $4 \mathrm{~km}$ to the south of this erosional feature (Fig. 2) where it apparently continues beyond the southern edge of the survey grid. However, to the north, Unit 4 is cut out by the erosive base of the overlying Unit 5 (Fig. 2). Unit 5 is the structurally youngest element of the infill sequence and has a distinctive "humped" appearance where it is c. $150 \mathrm{~m}$ thick and crops out on the seabed (see Figs. 2 and 4a). Bedding within Unit 5 (defined by short, irregular reflectors) is variably deformed and disrupted by a number of northerly dipping $\left(20^{\circ}-30^{\circ}\right)$ thrusts and, in the upper part of the unit, asymmetrical to symmetrical, upright to inclined $\left(25^{\circ}\right.$ to $\left.70^{\circ}\right)$ folds (Figs. 2 and $4 \mathrm{a}$ ). The relative intensity of this deformation increases upwards through Unit 5 with this thrusting and folding being most apparent within the thicker part of the sequence (Fig. 2). Importantly, Unit 5 is restricted to the northern part of the study area (see Fig. 2).

Unit 6 (up to c. $80 \mathrm{~m}$ thick) is the youngest part of the sequence and is correlated with the Forth Formation (Figs. 2, 3 and 4, and Table 1). The base of Unit 6 is a marked erosion surface defined by a high-amplitude, normal-polarity seismic reflector (see Figs. 4b, c). In the centre of the study area this erosion surface cuts out the well-bedded sediments of Unit 4 and cuts down into the horizontally bedded upper part of Unit 2, reaching a maximum depth of 195 ms TWTT (82 mBSB) (Fig. 2). In the northern part of the area, several curvilinear tracks 
are incised into the uppermost surface of Unit 5. These linear features are infilled with Unit 6 sediments and are interpreted as iceberg ploughmarks. Internally Unit 6 is relatively acoustically transparent with variably preserved bedding at its base passing upwards into an apparently massive sequence (Fig. 3). However, towards the north bedding is better developed, defined by a series of subhorizontal reflectors (Fig. 2).

\section{Thin-skinned glaciotectonism within the upper Aberdeen Ground Formation}

It is clear from the previous description that the upper part of the Aberdeen Ground Formation has been deformed by a series of northerly dipping thrusts and associated southerly verging folds. Thrusting has been identified at the same structural/lithostratigraphic level within the formation on both main- and cross-lines of the 2D HRS dataset (Figs. 2, 3 and 4). The relatively closely spaced nature of these survey lines (Fig. 1b) has enabled the thrusts and associated folds to be mapped across the survey area (Figs. 5 and 6). For ease of description the individual thrust-bound slices have been labelled TS1 (north) to TS14 (south) on Figs. 3, 5 and 6, with the associated thrusts T1 to T14. The dimensions and key structural characteristics of the individual thrust slices are summaries in Table 2. However, the key features of the imbricate thrust-stacked sequence are:

1. The individual thrust-slices have well-defined upper and lower surfaces with bedding within these detached (allochthonous) blocks having been locally folded by southerly verging, hanging-wall anticlines;

2. The individual thrusts (T4 to T14; Figs. 3 and 5) propagate upwards from a single detachment or décollement surface (Figs 2, 3 and 5) which occurs parallel to bedding within the underlying undeformed (autochthonous) Aberdeen Ground Formation sediments.

3. This basal décollement occurs at a depth of c. $220 \mathrm{mBSB}$ and is located at, or very close to, the top of a prominent, laterally extensive sheet sand (grey layer on Figs. 2, 3 and 4);

4. The length of the allochthonous blocks and spacing of the individual bounding thrusts decreases from north to south (Figs. 5 and 6) indicative of a greater degree of shortening towards the northern end of the imbricate thrust-stack;

5. Kinematic indicators, such as the offset on the individual thrusts and vergence of the hanging-wall anticlines, record a consistent S/SE-directed sense of transport indicating the thrust-stack developed during the same southerly directed deformation event;

6. Although thrusting and folding are largely confined within the upper part of the wellbedded Aberdeen Ground Formation (Unit1; Fig. 5c) this deformation also affects the lower part of the overlying unit (Unit 2; Fig. 5c). The relative intensity of this deformation decreases upwards through Unit 2.

Consequently, the simplest interpretation of the deformation present within the Aberdeen Ground Formation of the Central Graben of the North Sea is in terms of a thin-skinned thrust 
model which resulted in the detachment, transport and eventual stacking of a series of slablike blocks (TS1 to TS14) (Fig. 5). The southerly directed sense of transport recorded on the basal décollement as well as the individual thrusts (T1 to T14; Fig. 5) is consistent with deformation occurring in response to an ice advance from the N/NNW. Measurements made from the 2D seismic profiles indicate that the dip of the individual thrusts, in general, decreases from north to south across the survey area (Table 2) consistent with a forward (southerly) propagating imbricate thrust-stack. The overall style of thrusting and folding within this thrust-stack is consistent with ice-marginal to proglacial deformation observed in other areas, both onshore (Pedersen, 1993; Phillips et al., 2002; Benediktsson et al., 2008; Phillips et al., 2008; Aber et al., 1989; Bennett, 2001; Pedersen, 2000; Bakker, 2004; Andersen et al., 2005) and offshore (Ottesen et al. 2005; Andreassen et al. 2009; Andreassen et al., 2004; Rüther et al., 2013; Huuse et al., 2000a, b; Buckley, 2012a, b; Krzywiec et al., 2003; Cotterill et al., this volume). Furthermore the decrease in length of the individual detached blocks from south to north across the thrust stack (Table 2) is compatible with an increasing amount of shortening with the Aberdeen Ground Formation towards the proposed ice margin. This led to the more complex stacking of thrust slices TS1 to TS4 and increased thrust repetition of the Aberdeen Ground sediments immediately adjacent to the proposed ice margin located at, or very close to the northern termination of the imbricate thrust stack (sees Fig. 5).

The closely spaced nature of the survey lines (Fig. 1b) has enabled the 3D geometry of the imbricate thrust-stack to be mapped across the survey area (Figs. 5 and 6). Fig. 5a is a gridded surface of the basal décollement and the individual thrusts which propagate upwards from this detachment surface. From this figure it is clear that the main décollement which forms the base of the imbricate thrust stack is a relatively flat, planar surface consistent with it having exploited the pre-existing subhorizontal bedding/layering within the Aberdeen Ground Formation. Furthermore, it can be seen that the individual thrusts propagating from this detachment are laterally extensive (Figs. 5a and 6a). The larger of these structures can be traced along strike for at least $2 \mathrm{~km}$ and apparently continue to both the east and west of the current survey area, indicating that thrusting of the Aberdeen Ground Formation is even more extensive than revealed by this present study. The spacing of the thrusts decreases towards the north, with a number of the thrusts merging laterally to form apparently much larger structures; for example T9 and T10 towards the eastern margin of the survey area (Figs. 5a and 6a). Also apparent from Fig. 5a is that the individual thrust planes propagate to increasingly higher structural/stratigraphic levels within the Aberdeen Ground towards the south. This is potentially supported by the measured increase in the amount of displacement on the thrusts from north to south across the survey area (e.g. displacement on T7 $~ 18 \mathrm{~m}$ (north), T12 42m (south); Table 2). However, it can be seen on Fig. 5a that the vertical extent of the leading edge of the individual thrusts varies along strike (e.g. thrusts T9 and T12), suggesting that the amount of displacement accommodated by the thrusts is also likely to vary along the strike length of these structures.

Fig. 5b is the gridded upper surface of the imbricate thrust-stack which is interpreted as reflecting the topography of this surface and base of the overlying Unit 2 sediments (see 
Fig. 5c). The undulating nature of the surface indicates that it is unlikely to be tectonic; i.e. a roof thrust. The linear, ridge-like features picked out by this surface, in general, correspond to the large-scale, S/SSE-verging anticlines developed within the hanging-walls of the thrusts (compare Figs. 5b and c). The morphology of these ridges, which possess a relatively steeper southern face and more gently dipping northern slope, can be directly related to the asymmetrical shape of the structurally underlying folds and location of the major thrusts (compare Figs. 5b and c). However, the relatively large topographic feature located along the northern margin of the surface (Fig. 5b) corresponds to the stacking of thrust-slices TS1 to TS4, and is thought to represent the ice-proximal part of this thrust-complex. The limited areal extent of both TS3 and TS4 (Fig. 5c) is a result of these thrust slices being cut out laterally due to the increased relative intensity of thrusting in the northern part of the imbricate thrust-stack.

At its northern (ice-proximal) end, the thrust-stack terminates against the relatively steep, southern margin of the 2 to $4 \mathrm{~km}$ wide depression/incision (Figs. 2 and 5c). Importantly, the Aberdeen Ground Formation to the north of this approximately NE-SWtrending trench-like feature is unaffected by glacitectonism. This suggests that there is a direct spatial relationship between thin-skinned glacitectonism within the Aberdeen Ground and the formation of the trench. Consequently, this incised feature is thought to represent the primary source of at least some of the detached slabs of Aberdeen Ground sediments which were emplaced into the imbricate thrust-stack. This thrust-stack developed on the down-ice side of this glacitectonic "hollow". Although the initial formation of the "hollow" can be related to the detachment of the thrust slices (glacitectonic excavation) this feature clearly cuts downwards into the Aberdeen Ground Formation below the level of the décollement at the base of the thrust stack. This major detachment is clearly truncated by the trough, suggesting that this glacitectonic "hollow" was subsequently modified and overdeepened (see below). Although the morphology of the northern margin of the trough is consistent with it being a stepped erosion surface at the base of Unit 3, the southern side has been strongly modified by a number of N/NW-dipping normal (extensional) faults (Figs. 3 and 5c). This evidence can be used to suggest that the southern margin of the trough was unstable and may represent the ice-sediment contact on the up-ice side of the imbricate thrust-stack. On retreat of the ice this contact is likely to have become unstable with the normal (extensional) faulting recording the partial collapse of this former ice contact slope (see below).

As previously noted the acoustically distinct sequence overlying the imbricate thruststack (Unit 2 on Figs. 2, 3 and 5c) is also deformed. However, these sediments lack any significant thrusting and folding, and the relative intensity of this deformation decreases upwards through Unit 2 (see Fig. 5c). From the seismic data it appears that the weakly bedded sediments of Unit 2 infill the undulating upper surface of the folded and thrusted Aberdeen Ground Formation. If correct this suggests that the upper bounding surface of the imbricate thrust-stack (Fig. 5b) represents a palaeo-land surface and the linear ridges, glacitectonic thrust moraines (see below). Furthermore, the close correlation between the morphology of the ridges and the underlying large-scale glacitectonic structures (folds and thrusts) suggests that this surface suffered very little erosion during the deposition of Unit 2. 
The weakly deformed nature of the lower part of the Unit 2 can be used to suggest that deposition of at least the lower part of this sequence occurred during glacitectonism.

\section{Development of a major glacitectonic detachment within the Aberdeen Ground Formation}

Although large-scale glacitectonic thrust complexes have long been known from terrestrial (e.g. van der Wateren, 1986; Harris et al., 1995, 1997; Huuse and Lykke Andersen, 2000; Pedersen, 2000, 2005; Bakker, 2004; Andersen et al., 2005) and increasingly from marine environments (e.g. Andreassen et al., 2004; Ottesen et al., 2005; Andreassen et al. 2009; Rüther et al., 2013; Huuse et al., 2000a, b; Krzywiec et al., 2003; Cotterill et al., this volume) the conditions required for the initial development of a major detachment or décollement at the base of these thrust complexes remain poorly understood. Understanding how these major detachment surfaces are formed is fundamental to the development of a robust glacitectonic model which explains how large-scale thrust complexes develop and their relationship to ice sheet dynamics.

In the case of the imbricate thrust-stack deforming the Aberdeen Ground Formation, the basal décollement is located at, or very close to, the top of a prominent, laterally extensive sand sheet within this predominantly mud-rich sequence (see Figs. 2, 3 and 4). The overlying thrust-stack is approximately 90 to $100 \mathrm{~m}$ thick, suggesting that initial detachment occurred at a relatively deep level within the sediment pile. Other large-scale glacitectonic thrust complexes similarly possess a deep-seated (up to several hundred metres) basal décollement surfaces; for example, in the eastern Danish North Sea (Huuse et al. 2000) and the Dogger Bank 40 to $50 \mathrm{~m}$ (Cotterill et al., this volume). A number of authors have suggested that thrusting within glacigenic sequences, including the detachment of bedrock rafts, can be facilitated by the introduction of pressurised meltwater along the developing thrust planes (Bluemle and Clayton, 1984; Ruszczynska-Szenajch, 1987, 1988; Phillips and Merritt, 2008; Phillips et al., 2008; Burke et al., 2009). The periodic over pressurisation of subglacial meltwater systems can lead to hydrofracturing of the bed and thereby the introduction of pressurised meltwater (and sediment) into the substrate (Rijsdijk et al., 1999; van der Meer et al., 1999; Kjaer et al., 2003; Phillips et al., 2011). However, hydrofracturing on a scale required to promote the large-scale thrusting observed within the Aberdeen Ground Formation would have resulted in significant disruption of this sedimentary sequence which would have been apparent on the high-resolution 2D seismic data (see Figs. 2 to 4). However, the Aberdeen Ground in the Central Graben is apparently well-bedded, with bedding also being preserved within the detached thrust slices (see Fig. 5c).

The loading of the Aberdeen Ground Formation by a major ice sheet would have led to a direct increase in hydrostatic pressure within the pre-existing groundwater system. As noted above the basal décollement to the imbricate thrust-stack occurs close to, or at the top of a laterally extensive sand sheet (c. $8 \mathrm{~m}$ thick) within this predominantly mud-rich sequence. Such sand units have the potential to form discrete aquifers within the Aberdeen Ground, capped by the relatively impermeable clays. These muddy sediments would have 
confined the ground water to within the more permeable sands. Loading by the advancing ice sheet would not only have resulted in an increase in water pressure within the sands, but also the development of a significant hydrostatic gradient from higher pressures beneath the ice, through to much lower pressures at the ice margin and in its forefield. The development of a hydrostatic gradient would have forced ground water from beneath the ice (higher overburden pressure) into the forefield (lower pressure) in front of the advancing ice sheet. This process would have led to an increase in the water content of the sands immediately adjacent to the ice sheet margin. The result would have been a hydrostatic "pressure wave" within the bed which migrates forward in advance of the encroaching ice margin. The resultant increase in water pressure within the sands sheets within the Aberdeen Ground could have led to the lowering the cohesive strength of these sediments, eventually resulting in failure and the propagation of a water lubricated detachment out into the forefield. Once formed this detachment (bedding-parallel thrust) would have represented an ideal fluid pathway helping to further transmit pressurised water into the forefield and thereby facilitating the forward propagation of the developing imbricate thrust-stack.

The rate of ice sheet advance coupled with the permeability of the sands may have had a profound influence on the development of this pressurised ice-marginal groundwater system. During a relatively slow ice advance the hydrostatic pressure within the ground water system would have time to dissipate due to the higher permeability of the sands enabling the water to "leak away". However, during more rapid advance the rate at which groundwater is being expelled from the Aberdeen Ground beneath the ice could have exceeded the rate at which water was being transmitted through the sandy horizons and away from the ice sheet margin. The result would be a more pronounced increase in hydrostatic ground water pressures at a more rapidly advancing ice sheet margin. If correct, this mechanism could provide a potential link between the development of large-scale glacitectonic thrust complexes and rapid ice sheet advance (e.g. surge-type behaviour).

\section{Model linking glacitectonism of the Aberdeen Ground Formation to Middle Pleistocene ice sheet advance}

It is clear from the above that glacitectonism of the Aberdeen Ground Formation within the Central Graben of the North Sea can be directly related to the advance of a major Middle Pleistocene ice sheet across the region. For ease of description a five stage model is proposed to explain the evolution of this glacitectonised sequence (Fig. 7).

\section{Stage 1: Onset of thrusting in response to initial ice sheet advance}

The advance of the proposed ice sheet into the Central Graben region resulted in the loading of the underlying Aberdeen Ground Formation and the compaction-related pressurisation of the groundwater system within these sediments (Fig. 7a). Groundwater within this mud-rich sequence would have been primarily contained in the more permeable sands which probably formed laterally extensive aquifers within the Aberdeen Ground Formation. A hydrostatic gradient developed at the margin of the advancing ice sheet aided in the transmission of pressurised water from beneath the ice, through the sands and into the forefield (Fig. 7a). The 
resultant increase pore water pressure lowered the cohesive strength of the sands, eventually leading to failure of the sands and the initial propagation of a detachment at, or close to, the upper boundary of this laterally extensive unit. This décollement formed at a depth of c. 80 to $100 \mathrm{~m}$ leading to the progressive detachment of the sediments forming the upper part of the Aberdeen Ground Formation. Once formed this bedding-parallel thrust would have represented an ideal fluid pathway, focusing of fluid flow and aiding slip along this décollement surface. This may have led to "thrust gliding” (Nieuwland et al. 2000; Mourgues et al. 2006) aiding in the transmission of shear further out into the forefield of the advancing ice sheet and the detachment of elongate, slab-like blocks of the overlying Aberdeen Ground Formation sediments.

Shortening of the Aberdeen Ground Formation sediments as a result of ice-marginal to proglacial thrusting would have resulted in the formation of glacitectonic "hollow" at the northern, ice-proximal end of the evolving thrust stack (Fig. 7b). This hollow is likely to have developed beneath the ice sheet margin (sub-marginal) and therefore would not only resulted in the progressive thickening of this margin, but also the transmission of the compressional force generated by the advancing ice mass to a much deeper level within the Aberdeen Ground Formation. The transmission of this “ice-push” deeper into the sediment pile would have provided the driving force required for the forward propagation of the developing thrust-stack (Fig. 7c).

The progressive shortening of the sediment pile was achieved by the sequential development of a number of smaller scale thrusts which ramp upwards from the basal décollement into the overlying Aberdeen Ground Formation sediments. These thrusts become relatively younger towards the southern, distal limit of the developing thrust-stack (T1 oldest, T14 - youngest; Fig. 5c). Consequently, the earliest (oldest) thrusts, as well as the most intense deformation, occur adjacent to the ice margin. Importantly, as the sequence continues to deform the sub-marginal glacitectonic "hollow" becomes progressively larger as a result of the shortening of the sediment pile in front of the advancing ice sheet (see Fig. 7a to c).

\section{Stage 2: progressive development of a large-scale imbricate thrust-stack and associated glacitectonic landform development and penecontemporaneous ice marginal sedimentation}

As the imbricate thrust-stack continued to develop the individual thrusts (T1 to T14, Fig 5c) propagated upward through the Aberdeen Ground Formation, transporting the detached blocks of Aberdeen Ground Formation (TS1 to TS14 respectively, Fig. 5c) to progressively high structural levels within the deforming sequence. Thrusting of the detached blocks was accompanied by large-scale, southerly directed folding of bedding within these allochthonous blocks (Fig. 7c). Eventually the combination of thrusting and associated folding began to be revealed on the palaeo-land surface in front of the advancing ice sheet (see Fig. 7c and d). The result was the progressive development of a series of morainic landforms located immediately above the upward propagating thrusts and folds (Figs. 5b and 8). This glacitectonic landsystem, shown in Fig. 8, is characterised by a series curvilinear, ridge-like, thrust moraines, orientated parallel to the advancing ice margin, separated by a series of low- 
lying areas. These linear, low-lying basins were progressively filled by glaciofluvial outwash laid down by meltwater emanating from the advancing ice sheet (c.f. Phillips et al., 2008), as well as debris-flows derived from the relatively unstable slopes of the developing thrust moraines (Unit 2, Figs. 7 and 8). As this landsystem continued to evolve the thrusts and folds propagated upwards through the sequence deforming the earlier lower part of Unit 2 outwash sequence (see Figs. 2, 3 and 7d).

\section{Stage 3: cessation of thin-skinned deformation, post-glacitectonic sedimentation and ice sheet retreat}

Eventually, forward propagation of the thrust-stack would have ceased, either due to the ice sheet reaching its (?local) maximum extent, or alternatively, as a result of the dewatering of the basal décollement and the locking up of this detachment. As the thrusts within the imbricate thrust-stack propagated through the Aberdeen Ground Formation they would have eventually come close to, or have intersected the palaeo-land surface (see Fig. 8).

Hydrofracturing of the overlying sediments would then have enabled the pressurised groundwater to drain from the deforming sediment pile and in particular the basal décollement. This probably occurred as a series of springs or "burst-out" features (Benediktsson et al., 2008) located along the base of the thrust moraines and marking the position of the underlying thrusts (Fig. 8). As forward propagation of the thrust-stack switched off, further forward movement of the ice sheet is thought to have pushed into the northern end of the deformed sequence leading to the more complex deformation and thrustrepetition observed in this ice-proximal part of the thrust-stack (see Figs. 7d) Whilst the ice sheet was still at its "maximum" position within the Central Graben area, meltwater issuing from the ice would have led to the continued deposition (post-glacitectonic) of the Unit 2 outwash sequence which initially mantled and then buried the glacitectonic landsystem preserving these landforms which form the upper surface of the deformed sedimentary sequence (Figs. 5b, 7 and 8).

The subsequent retreat of the Mid-Pleistocene ice sheet from the Central Graben region revealed the glacitectonic "hollow" located beneath its margin (Fig. 7). This "hollow" would have captured any meltwater flowing from the retreating ice sheet resulting in erosion and the over-deepening of this feature, as well as deposition of glacifluvial outwash (Unit 3 on Fig. 7). Furthermore the retreat of the ice would have left unsupported the relatively steep, former ice-contact slope on the up-ice (proximal) side of the thrust-stack. This slope is likely to have been relatively unstable and prone to collapse leading not only to the modification of the southern margin of the "hollow" due to normal (extensional) faulting (Figs. 3, 5 and 7), but also the generation of mass flows which ran down into this topographic feature.

The continued retreat of the ice sheet eventually revealed the whole of the hollow with its chaotic basal sequence of ice-proximal glacifluvial deposits and mass flows (Unit 4). These early sediments only partially filled the "hollow" which continued to act as a depocentre for a more distal glacifluvial outwash and possibly glaciolacustrine sediments due to the ponding of meltwater (Unit 4; Figs. 3, 5 and 7e and f). As down-wasting of the ice sheet continued melt-water availability increased leading to the deposition of a more widespread, regional drape of glaciofluvial sediments (Fig. 7f). 


\section{Stage 4: minor late Middle-Pleistocene readvance}

Deformation affecting the upper part of the sedimentary sequence (Units 4 and 5 ) is thought to record a ?minor readvance of the ice sheet into the Central Graben region possibly during late Mid-Pleistocene. Readvance of the ice reworked the upper part of Unit 4 sediments to form the glacitectonised sequence of Unit 5 as well as a prominent push-moraine at its margin (Fig. 7g). The geometry of the thrusts and folds within Unit 5 indicate that once again ice advance was from the north.

\section{Stage 5: Weichselian to recent evolution}

The Mid-Pleistocene sequence is overlain by a regional drape of well-bedded, acoustically transparent sediments (Fig. 7h) interpreted as representing the Weichselian (Devensian) Forth Formation (Unit 6). The base of the Forth Formation is marked by a gently undulating, but well-defined acoustic reflector, which is recognised throughout the central North Sea on multiple commercial seismic datasets and via geotechnical (core log) sampling. These data sets also record the presence of iceberg ploughmarks incised into this boundary (i.e. into uppermost sediments of Units 4) as well as within the Forth Formation, thereby recording the presence of a marine terminating Weichselian ice sheet. Following the end of the Weichselian glaciation, the final stages of the evolution of the Central Graben region are dominated by sea level rise and establishing of the modern seabed (Fig. 7i).

\section{Conclusions}

The results of a high-resolution 2D seismic survey of Mid-Pleistocene glaciogenic sediments in the Central Graben region of the central North Sea reveal that rather than being a simple layer cake they have been subject to significant glacitectonic disturbance. Glacitectonism was characterised by large-scale thrusting and folding associated the repeated southerly advance of an ice sheet across the region during the Mid-Pleistocene. A thin-skinned glacitectonic model involving ice-marginal to proglacial deformation followed by the deposition of an outwash sequence on retreat of the ice is proposed. Initial ice advance into the Central Graben area led to the over-pressurising of groundwater within a laterally extensive sand sheet in the upper Aberdeen Ground Formation. This facilitated the formation of a major detachment surface located within this sand sheet which formed at the basal décollement to the imbricate thrust-stack. Dewatering of this décollement led to the eventual cessation of thrusting. Subsequent retreat of the ice sheet was accompanied by the deposition of a complex glacifluvial outwash sequence which was itself deformed during later minor readvance of the ice from the north. The proposed model provides clear evidence that Midd-Pleistocene ice sheet dynamics within the Central Graben of the North Sea was far more complex than previously thought.

\section{Acknowledgements}

Permission to publish this 2D HRS dataset was kindly granted by Luis McArthur and Eric Cauquil, on behalf of Total Exploration and Production UK Ltd, and by Ken Games and Ed 
Self of Gardline Geosurvey Limited. The authors are therefore grateful to the above companies for their collaboration and contribution towards this research. Mads Huuse and an anonymous correspondent are thanked for the comments on an earlier draft of this paper. ERP publishes with the permission of the Executive Director of the British geological Survey, Natural Environmental Research Council (NERC).

\section{References}

Aber, J.S. 1988. Ice-shoved hills of Saskatchewan compared with Mississippi Delta mudlumps - Implications for glaciotectonic models. In Croot, D.G. (ed.) Glaciotectonics: Forms and Processes, Balkema, Rotterdam.

Aber, J.S., Croot, D.G., and Fenton, M.M. 1989. Glaciotectonic landforms and structures. Kluwer, Dordrecht.

Andersen, L.T., Hansen, D.L. and Huuse, M. 2005 Numerical modelling of thrust structures in unconsolidated sediments: implications for glaciotectonic deformation. Journal of Structural Geology 27, 587-596

Andreassen, K., Nielsen, L.C., Rafaelsen, B. and Kuilman, L. 2004. Three-dimensional seismic data from the Barents Sea margin reveal evidence of past ice streams and their dynamics. Geology 32, 729-732.

Andreassen, K. and Winsborrow, M. 2009. Signature of ice streaming in Bjornoyrenna, Polar North Atlantic, through the Pleistocene and implications for ice-stream dynamics. Annals of Glaciology 50, 17-26.

Banham, P. 1975. Glaciotectonic Structures: A general discussion with particular reference to the contorted drift of Norfolk. In Wright, A.E. and Moseley, F. (eds.): Ice Ages: Ancient and Modern, 69-94, Seel House Press, Liverpool.

Banham, 1988. Thin-skinned glaciotectonic structures. In: Croot, D. G. (Ed.) Glaciotectonics: Forms and Processes, 21-25. Rotterdam, A.A. Balkema.

Baroni, C. and Fasano, F. 2006. Micromorphological evidence of warm-based glacier deposition from the Ricker Hills Tillite (Victoria Land, Antarctica). Quaternary Science Reviews 25, 9-10, 976-992.

Beaumont, P., Turner, J. and Ward, F.P. 1969. An Ipswichian peat raft in glacial till at Hutton Henry, County Durham. New Phytologist 68, 797-805.

Bennett, M.R. 2001. The morphology, structural evolution and significance of push moraines. Earth Science Reviews 53, 197-236.

Ber, A. 1986. Glaciotectonic deformation of glacial landforms and deposits in the Suwalki Lakeland (NE Poland). In van der Meer, J.J.M. (ed.): Tills and Glaciotectonics, Balkema, Rotterdam, 135-144, Balkema, Rotterdam. 
Berthelsen, A. 1979. Recumbant folds and boudinage structures formed by subglacial shear: an example of gravity tectonics. Geologie en Mijnhouw 58, 253-260.

Bluemle, J.P. and Clayton, L. 1984. Large-scale glacial thrusting and related processes in North Dakota. Boreas 13, 279-299.

Boulton, G.S., Caban, P.E., and van Gijssel, K. 1995. Groundwater flow beneath ice sheets: Part I - Large scale patterns. Quaternary Science Reviews 14, 545-563.

Boulton, G.S., Dent, D.L., and Morris, E.M. 1974. Subglacial shearing and crushing, and the role of water pressures in tills from south-east Iceland. Geografiska Annaler 56A, 135-145.

Boulton, G.S., Dobbie, K.E. and Zatsepin, S. 2001. Sediment deformation beneath glaciers and its coupling to the subglacial hydraulic system. Quaternary International 86, 3-28.

Boulton, G.S., van der Meer, J.J.M., Hart, J., Beets, D., Ruegg, G.H.J., van der Wateren, F.M., Jarvis, J. 1996. Till and moraine emplacement in a deforming bed surge - an example from a marine environment. Quaternary Science Reviews 15, 10, 961-987.

Buckley, F.A. 2012a. An Early Pleistocene grounded ice sheet in the Central North Sea. In Huuse, M., Redfern, J., Le Heron, D.P., Dixon, R.J., Moscariello, A. and Craig, J. (eds.): Glaciogenic Reservoirs and Hydrocarbon Systems, 1-28, Geological Society, London, Special Publication 368.

Buckley, F.A. 2012b. An ice-moulded surface from the middle Pleistocene of the central North Sea. Near Surface Geophysics 10, 331-344.

Burke, H., Phillips, E.R., Lee, J.R. and Wilkinson, I.P. 2009. Imbricate thrust-stack model for the formation of glaciotectonic rafts: An example from the Middle Pleistocene of north Norfolk, UK. Boreas 38, 620-637.

Cameron, T.D.J., Crosby, A., Balson, P.S., Jeffrey, D.H., Lott, G.K., Bulat, J. and Harrison, D.J. 1992. United Kingdom Offshore Report: The geology of the southern North Sea. (London: HMSO for the British Geological Survey).

Cameron, T.D.J, Stoker, M.S. and Long, D. 1987. The history of Quaternary sedimentation in the UK sector of the North Sea basin. Journal of the Geological Society of London 144, 4358.

Carr, S.J., Holmes, R., van der Meer, J.J.M. and Rose, J. 2006. The Last Glacial Maximum in the North Sea Basin: Micromorphological evidence of extensive glaciation. Journal of Quaternary Science 21, 131-153.

Croot, D.G. 1987. Glacio-tectonic structures: a mesoscale model of thin-skinned thrust sheets? Journal of Structural Geology 9, 7, 797-808.

Ehlers, J. and Wingfield, R. 1991. The extention of the Late Weichselian / Late Devensian ice sheet in the North Sea basin. Journal of Quaternary Science 6, 313-326. 
Evans, D.J.A. 2007. Glaciotectonic Structures and Landforms. In Elias, S. (ed.): Encyclopedia of Quaternary Science, 772-784, Elsevier, Amsterdam.

Evans, D.J.A., Phillips, E.R., Hiemstra, J.F. and Auton, C.A. 2006. Subglacial till: Formation, sedimentary characteristics and classification. Earth Science Reviews 78, 1-2, 115-176.

Fyfe, J.A. 1986. FISHER (56º N-02E) 1:250 000 Quaternary Geology Map Sheet. British Geological Survey.

Gatliff, R.W., Richards, P.C., Smith, K., Graham, C.C., McCormac, M., Smith, N.J.P., Long, D., Cameron, T.D.J., Evans, D., Stevenson, A.G., Bulat, J. and Ritchie, J.D. 1994. United Kingdom Offshore Regional Report: The Geology of the central North Sea, 79-93 (London: HMSO for the British Geological Survey).

Harris, C. and Murton, J.B. 2005. Interactions between glaciers and permafrost: an introduction. Geological Society of London, Special Publications 242, 1-9.

Hart, J.K. 1990. Proglacial glaciotectonic deformation and the origin of the Cromer Ridge push moraine complex, north Norfolk, England. Boreas 19, 165-180.

Hart, J.K. and Boulton, G.S. 1991. The interrelation of glaciotectonic and glaciodepositional processes within the glacial environment. Quaternary Science Reviews 10, 4 335-350.

Hart, J.K. and Rose, J. 2001. Approaches to the study of glacier bed deformation. Quaternary International 86, 1, 45-58.

Hiemstra, J.F., Evans, D.J.A., Ó Cofaigh, C. 2007. The role of glaciotectonic rafting and comminution in the production of subglacial tills: Examples from southwest Ireland and Antarctica. Boreas 36, 386-399.

Holcombe, R. 2012. GeoCalculator 4.9.6., available online at:

http://www.holcombe.net.au/software/rodh_software

Holmes, R. 1977. Quaternary deposits of the central North Sea: 5. The Quaternary geology of the UK sector of the North Sea between $56^{\circ}$ and $58^{\circ} \mathrm{N}$, Volume 5, 1-50 (London: HMSO for the British Geological Survey).

Huuse, M., and Lykke-Andersen, H., 2000. Large-scale glaciotectonic thrust structures in the eastern Danish North Sea. In Maltman, A.J., Hubbard, B., Hambrey, M.J. (eds.): Deformation of Glacial Materials, Geological Society Special Publication 176, 293-305.

Jakobsen, P.R. 1996. Distribution and intensity of glaciotectonic deformation in Denmark. Bulletin of the Geological Society of Denmark 42, 175-185.

Knudsen, K.L. and Sejrup, H.P. 1993. Pleistocene stratigraphy in the Devil's Hole area, central North Sea: Foraminiferal and amino acid evidence. Journal of Quaternary Science 8, $1-14$. 
Knudsen, K.L. and Sejrup, H.P. 2008. Amino acid geochronology of selected interglacial sites in the North Sea area. Boreas 17, 347-354.

Kjaer, K.H., Krüger, J. and van der Meer, J.J.M. 2003. What causes till thickness to change over distance? Answers from Mýrdalsjökull, Iceland. Quaternary Science Reviews 22, 16871700 .

Kjaer, K.E., Larson, E., van der Meer, J.J.M., Ingolfsson, O., Kruger, J., Benediktsson, I.O., Knudsen, C.G. and Schomacker, A. 2006. Subglacial decoupling at the sediment/bedrock interface: A new mechanism for rapid flowing ice. Journal of Quaternary Science 25, 27042712 .

Krzywiec, P., Kramarska, R. and Zientara, P. 2003. Strike-slip tectonics within the SW Baltic Sea and its relationship to the inversion of the mid-Polish trough - evidence from highresolution seismic data. Tectonophysics 373, 93-105.

Lee, J.R., and Phillips, E.R. 2008. Progressive soft sediment deformation within a subglacial shear zone - a hybrid mosaic-pervasive deformation model for Middle Pleistocene glaciotectonised sediments from eastern England. Quaternary Science Reviews 27, 13-14, 1350-1362.

McCarroll, D. and Rijsdijk, K.F. 2003. Deformation styles as a key for interpreting glacial depositional environments. Journal of Quaternary Science 18, 473-489.

Moran, S.R., Clayton, L., Hooke, R.L., Fenton, M.M. and Andriashek,, L.D. 1980. Glacierbed landforms of the prairie region of North America. Journal of Glaciology 25, 457-467.

Mourgues, R. and Cobbold, P.R. 2006. Sandbox experiments on gravitational spreading and gliding in the presence of fluid overpressures. Journal of Structural Geology 28, 887-901.

Nieuwland, D.A., Leutscher, J.H. and Gast, J. 2000. Wedge equilibrium in fold-and-thrust belts: prediction of out-of-sequence thrusting based on sandbox experiments and natural examples. Geologie en Mijnbouw 79, 81-91.

Ottesen, D., Dowdeswell, J.A. and Rise, L. 2005. Submarine platforms and the reconstruction of fast-flowing ice streams within a large Quaternary ice sheet: The 2,500 km-long Norwegian-Svalbard margin ( $57^{\circ}$ to $\left.80^{\circ} \mathrm{N}\right)$. Geological Society of America Bulletin 117, 1033-1050.

Peacock, J.D. and Merritt, J.W. 1997. The Tynacoille-Blackrock ridge: A possible ice front position for the glacier occupying Loch Indaal. In Dawson, A.G. and Dawson, S. (eds.): Quaternary of Isle of Jura and Islay, field guide, 60-65, Quaternary Research Association, Cambridge.

Pedersen, S.A.S. 1987. Comparative studies of gravity tectonics in Quaternary sediments and sedimentary rocks related to fold belts. Geological Society of London, Special Publications 29, 165-179. 
Pedersen, S.A.S. 2000. Superimposed deformation in glaciotectonics. Bulletin of the Geological Society of Denmark 46, 125-144.

Pedersen, S.A.S. 2005. Structural analysis of the Rubjerg Knude Glaciotectonic Complex, Vendsyssel, northern Denmark. Geological Survey of Denmark and Greenland Bulletin 8, 192pp

Phillips, E.R., Evans, D.J.A. and Auton, C.A. 2002. Polyphase deformation at an oscillating ice margin following the Loch Lomond Readvance, central Scotland, UK. Sedimentary Geology 149, 1-3, 157-182.

Phillips, E.R. and Merritt, J. 2008. Evidence for multiple water-escape during rafting of shelly marine sediments at Clava, Inverness-shire, NE Scotland. Quaternary Science Reviews 27, 245-257.

Phillips, E.R., Lee, J.R. and Burke, H. 2008. Progressive proglacial to subglacial deformation and syntectonic sedimentation at the margins of the Mid-Pleistocene British Ice Sheet: Evidence from north Norfolk, UK. Quaternary Science Reviews 27, 1848-1871.

Rijsdijk, K.F., Owen, G., Warren, W.P., McCarroll, D., van der Meer, J.J.M. 1999. Clastic dykes in consolidated tills: Evidence for subglacial hydrofracturing at Killiney Bay, eastern Ireland. Sedimentary Geology 129, 111-126.

Rüther, D.C., Andreassen, K. and Spagnolo, M. 2013. Aligned glaciotectonic rafts on the central Barents Sea seafloor revealing extensive glacitectonic erosion during the last deglaciation. Geophysical Research Letters 40, 6351-6355.

Ruszczynska-Szenajch, H. 1987. The origin of glacial rafts: Detachment, transport, emplacement. Boreas 16, 113-117.

Ruszczynska-Szenajch, H. 1988. Glaciotectonics and its relationship to other glaciogenic processes. In Croot, D.G. (ed.) Glaciotectonics: Forms and Processes, 191-194, Balkema, Rotterdam.

Schack Pedersen, S.A. 2000. Superimposed deformation in glaciotectonics. Bulletin of the Geological Society of Denmark 46, 125-144.

Sejrup, H.P., Nygård, A., Hall, A.M. and Haflidason, H. 2008. Middle and Late Weichselian (Devensian) glaciation history of south-western Norway, North Sea and eastern UK. Quaternary Science Reviews 28, 370-380.

Sejrup, H.P., Aarseth, K.L., Ellingsen, E., Reither, E. and Jansen, E. 1987. Quaternary stratigraphy of the Fladen area, central North Sea: a multidisciplinary study. Journal of Quaternary Science 2, 35-59

Stoker, M.S. and Bent, A.J.A. 1985. Middle Pleistocene glacial and glaciomarine sedimentation in the west central North Sea. Boreas 14, 325-332. 
Stoker, M.S. and Bent, A.J.A. 1987. Lower Pleistocene deltaic and marine sediments in boreholes from the central North Sea. Boreas 2, 87-96.

Stoker, M.S., Skinner, A.C., Fyfe, J.A., and Evans, D. 1985 The Quaternary succession on the Northern UK Continental Shelf and Slope: Implications for regional geotechnical investigations. In Ardus, D.A. (ed.): Offshore Site Investigation 85, SUT Conference Proceedings 45-61, Graham and Trotman, London.

Stoker, M.S., Long, D. and Fyfe, J.A. 1985. A revised Quaternary stratigraphy for the central North Sea. Newsletters on Stratigraphy 12, 119-128.

Stoker, M.S., Balson, P.S., Long, D. and Tappin, D.R. 2011. An overview of the lithostratigraphical framework for the Quaternary deposits on the United Kingdom continental shelf. British Geological Survey Research Report, RR/11/03.

van Gijssel, K. 1987. A lithostratigraphic and glaciotectonic reconstruction of the Lamstedt Moraine, Lower Saxony (FRG). In van der Meer, J.J.M. (Ed.): Tills and Glacitectonics, 145156, A.A. Balkema, Rotterdam.

van der Meer, J.J.M., Kjaer, K.H., Krüger, J. 1999. Subglacial water-escape structures and till structures, Sléttjökull, Iceland. Journal of Quaternary Science 14, 191-205.

van der Wateren, D. 1986. Structural geology and sedimentology of the Dammer Berge push moraine, FRG. In van der Meer, J.J.M. (Ed.): Tills and Glacitectonics, 157-182, A.A.

Balkema, Rotterdam.

van der Wateren, F.M., Kluiving, S.J. and Bartek, L.R. 2000. Kinematic indicators of subglacial shearing. In: Maltman, A.J., Hubbard, B., Hambrey, J.M. (Eds.), Deformation of Glacial Materials. Journal of the Geological Society, London, Special Publications, Vol. 176, 259-291.

Vaughan-Hirsch, D.P., Phillips, E.R., Hart, J.K. and Lee, J. 2012. Micromorphological analysis of poly-phase deformation associated with the transport and emplacement of glaciotectonic rafts at West Runton, north Norfolk, UK. Boreas 42, 376-394.

West, R.G. 1980. Pleistocene forest history in East Anglia. New Phytologist 85, 571-622.

Wingfield, R. 1990. The origin of major incisions within the Pleistocene deposits of the North Sea. Marine Geology 91, 31-52.

\section{Figures}

Fig. 1. A) general location map. B) line plan map inset.

Fig. 2. Data example - centreline i) Uninterpreted and ii) Interpreted.

Fig. 3. Data example - detailed inline example showing labelled thrust-related structures i) Uninterpreted and ii) Interpreted. 
Fig. 4. Data example - cross line through central raft section, showing imbricate sequence i) Uninterpreted and ii) Interpreted.

Fig. 4b. Data example - cross line i) Uninterpreted and ii) Interpreted.

Fig. 4c. Data example - cross line i) Uninterpreted and ii) Interpreted.

Fig. 4d. Data example - cross line i) Uninterpreted and ii) Interpreted.

Fig. 5. 3D visualisation of raft bounding surface lower decollement surface upper coherent surface of raft body context of surfaces related to survey centreline profile.

Fig. 6. Raft thickness and structural orientation diagrams.

Fig. 7. Raft development model.

Fig. 8. Illustration showing palaeo-landsystem (sedimentary infill environment of model stage 1c).

\section{Tables}

Table 1. Lithostratigraphic framework for the Central Graben, central North Sea (after Stoker et al. 2011, comprising Holmes, 1977; Stoker et al., 1985; Sejrup et al., 1987; Knudsen and Sejrup, 1993; Gatliff et al., 1994).

Table 2. Table summarising the structural features of the individual thrust-bound blacks formed in the imbricate thrust stack identified within the Aberdeen Ground Formation of the Central Graben, central North Sea. Dip and dip direction data obtained for the individual thrusts are displayed graphically on Fig. 6. 
Table 2.

\begin{tabular}{|c|c|c|c|}
\hline Thrust Slice Number & Length & Thickness & Description \\
\hline TS1-TS4 & & & $\begin{array}{l}\text { TS1 to TS4 represent the most extensively stacked, deformed, and most steeply inclined } \\
\left(>30^{\circ}\right) \text { thrust slices within the survey area. TS1 structurally underlies TS2 and TS3. It is } \\
\text { internally deformed; particularly towards its northern end where it is cut by several } \\
\text { closely-spaced, steeply inclined, northerly-dipping thrusts. TS2 and TS3 occur within the } \\
\text { hanging-walls of two steeply northerly dipping reverse faults. The upper surfaces of TS2 } \\
\text { and TS3 occur at c. } 85 \text { mBSB }\end{array}$ \\
\hline TS5 & $250 \mathrm{~m}$ & $35-75 \mathrm{~m}$ & The thrust at the base of TS5 dips at $19^{\circ}$ towards $020^{\circ}(\mathrm{NNE})$ \\
\hline TS6 & $450 \mathrm{~m}$ & $35-65 \mathrm{~m}$ & The thrust at the base of TS6 dips at $18^{\circ}$ towards $017^{\circ}$ (NNE) \\
\hline TS7 & $250 \mathrm{~m}$ & $35 \mathrm{~m}$ & $\begin{array}{l}\text { The thrust at the base of TS7 dips at } 15^{\circ} \text { towards } 005^{\circ}(\mathrm{N}) \text {. The estimated displacement } \\
\text { across thrust T7 is c. } 18 \mathrm{~m} \text {. Asymmetrical folds which deform bedding within TS7 trend } \\
\text { approximately E-W (trend c. } 070^{\circ}-080^{\circ} \text { ) }\end{array}$ \\
\hline TS8 & $350 \mathrm{~m}$ & $\begin{array}{l}\text { c. } 65 \mathrm{~m} \text { (range } 35 \mathrm{~m} \text { in } \\
\text { east of survey area to } 75 \\
\mathrm{~m} \text { in the west) }\end{array}$ & $\begin{array}{l}\text { The thrust at the base of TS7 dips at } 11^{\circ} \text { towards } 354^{\circ}(\mathrm{N}) \text {. The estimated displacement } \\
\text { across thrust T8 is c. } 29 \mathrm{~m} \text {. Locally developed upright folds within TS8 trend at c. } 077^{\circ}\end{array}$ \\
\hline TS9 & 550 up to $>600 \mathrm{~m}$ & $65-75 \mathrm{~m}$ & $\begin{array}{l}\text { TS9 is a sigmoidal to S-shaped slab. The length of this detached block varies from c. } 550 \\
\mathrm{~m} \text { in the centre of the survey area, up to }>600 \mathrm{~m} \text { along the eastern margin of the survey } \\
\text { grid. The thrust at the base of TS9 dips at } 11^{\circ} \text { towards } 347^{\circ} \text { (NNW). Displacement across } \\
\text { T9 is c. } 42 \mathrm{~m} \text {, but is seen to vary from west to east across the survey area }\end{array}$ \\
\hline TS10 & 180 up to $500 \mathrm{~m}$ & $\begin{array}{l}45-55 \text { m thick (max } \\
\text { thickness } 75 \mathrm{~m} \text { in north of } \\
\text { survey area) }\end{array}$ & $\begin{array}{l}\text { The length of this detached block varies from c. } 180 \mathrm{~m} \text { in the centre of the survey area, up } \\
\text { to }>500 \mathrm{~m} \text { along the western margin of the survey grid. The thrust at the base of TS10 } \\
\text { dips at } 10^{\circ} \text { towards } 351^{\circ}(\mathrm{NNW}) \text {. Displacement across T10 is c. } 38 \mathrm{~m}\end{array}$ \\
\hline TS11 & $690 \mathrm{~m}$ & & $\begin{array}{l}\text { The thrust at the base of TS11 dips at } 8^{\circ} \text { towards } 347^{\circ}(\mathrm{NNW}) \text {. In the west of the survey } \\
\text { area TS11 is deformed by a back-thrust which dips at } 45^{\circ} \text { towards the south. In the east of } \\
\text { the survey area TS11 divides and is structurally underlain by a } 500 \mathrm{~m} \text { long, }>600 \mathrm{~m} \text { wide } \\
\text { and } 65 \mathrm{~m} \text { thick thrust slice TS11a }\end{array}$ \\
\hline TS12 & $580 \mathrm{~m}$ & $65-70 \mathrm{~m}$ & $\begin{array}{l}\text { The thrust at the base of TS12 dips at } 10^{\circ} \text { towards } 344^{\circ} \text { (NNW). Displacement across T12 } \\
\text { is c. } 42 \mathrm{~m} \text {. TS12 is deformed by a back-thrust which dips at } 35^{\circ} \text { towards } 165^{\circ}\end{array}$ \\
\hline TS13 & $600 \mathrm{~m}$ & $50-60 \mathrm{~m}(\max 70 \mathrm{~m})$ & $\begin{array}{l}\text { The thrust at the base of TS13 dips at } 6^{\circ} \text { towards } 345^{\circ} \text { (NNW). Displacement across T13 } \\
\text { is c. } 10 \mathrm{~m} \text {. The distal/leading edge of TS13 is arcuate in shape. TS13 is locally deformed } \\
\text { by a back-thrust which dips at } 30-40^{\circ} \text { towards the north with a throw of } 5-10 \mathrm{~m}\end{array}$ \\
\hline TS14 & $330 \mathrm{~m}$ & $35-65 \mathrm{~m}$ & $\begin{array}{l}\text { The thrust at the base of TS14 dips at } 3^{\circ} \text { towards } 031^{\circ}(\mathrm{NE}) \text {. Displacement across T14 is c. } \\
18 \mathrm{~m}\end{array}$ \\
\hline
\end{tabular}




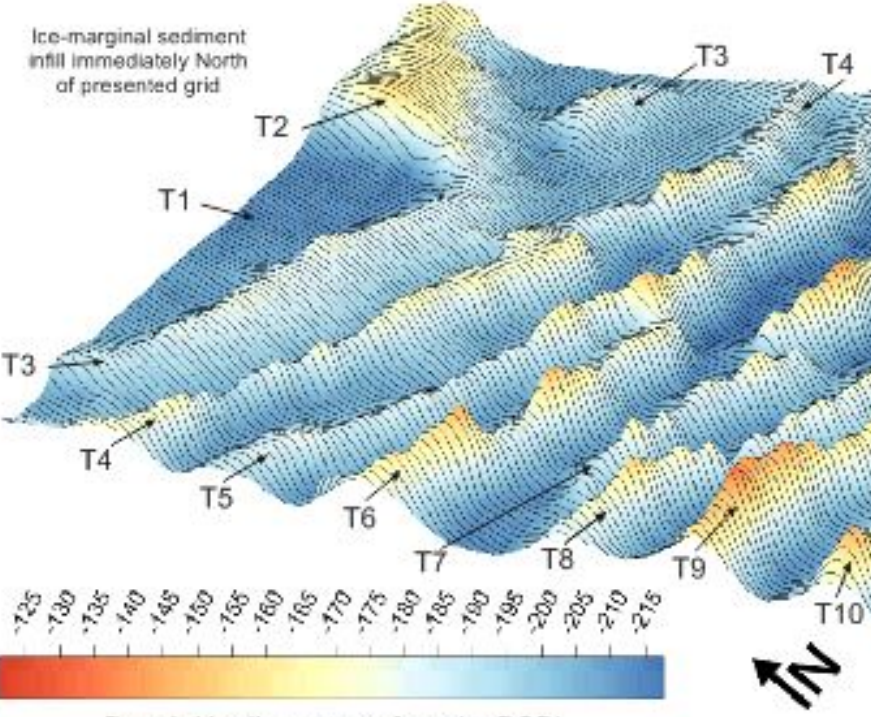

Basal décollement surface (m BSB)

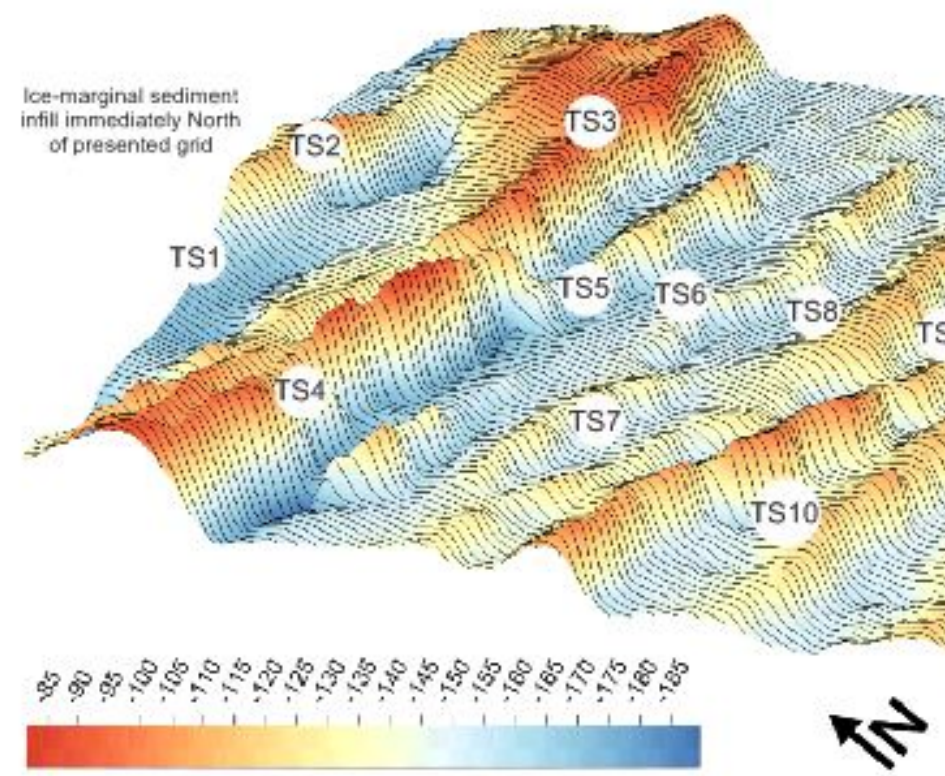

Upper coherent surface of rafting (m BSB)

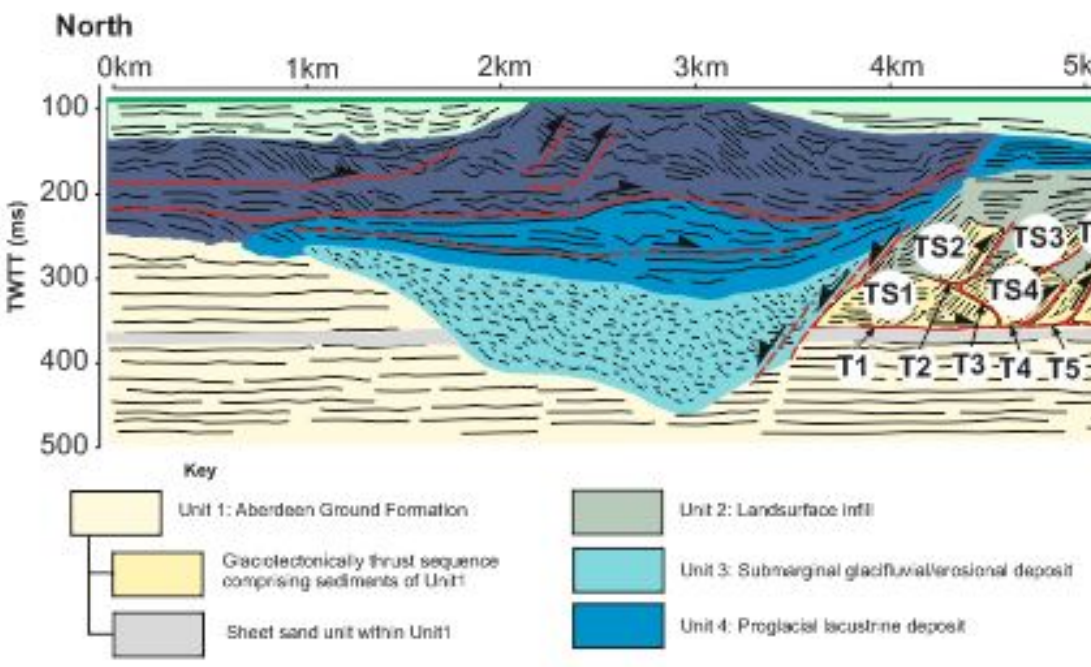

a) Gridded surface showing the depth of the basal décollement, with individual reverse-thrust planes identified

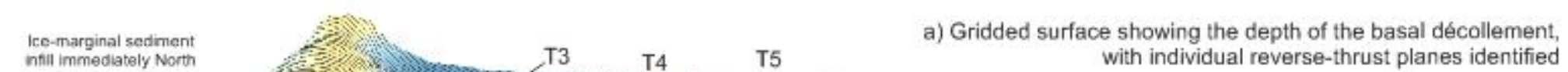


a) Plan view of thrust slices, showing total thickness

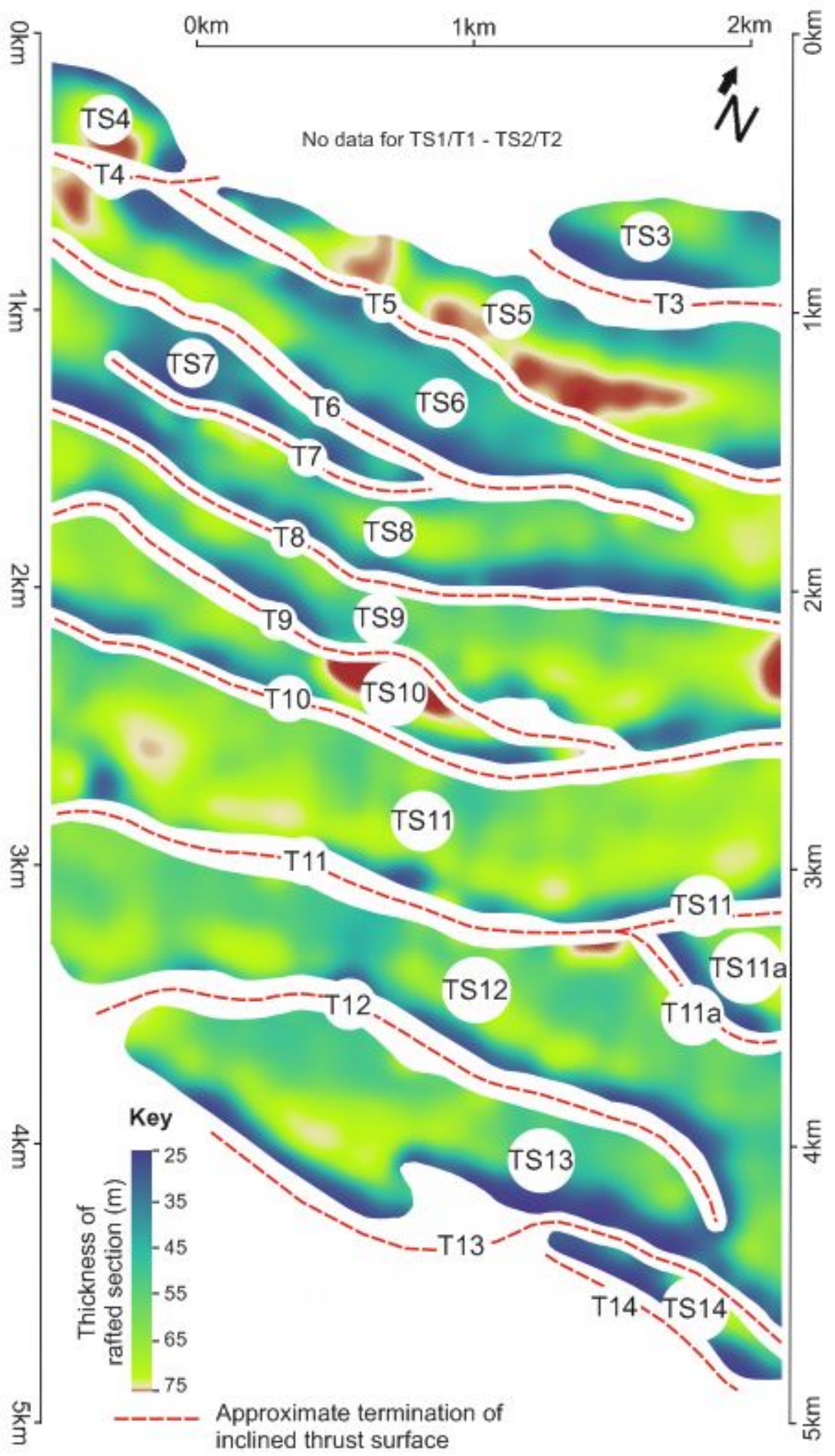

b) Tectonic direction associated with thrust slices TS5 - T14

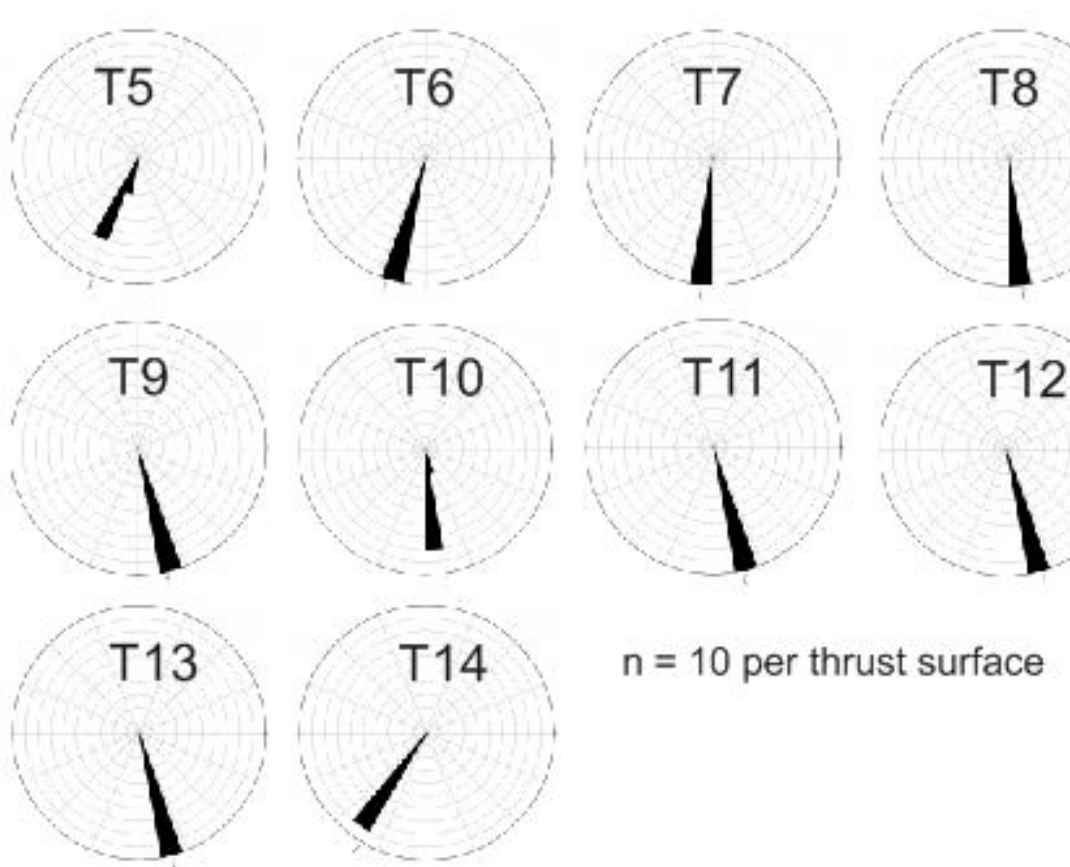

c) Inferred dip/dip dir orientations overlaid upon

resultant tectonic direction for reverse-thrust surfaces T5 - T14

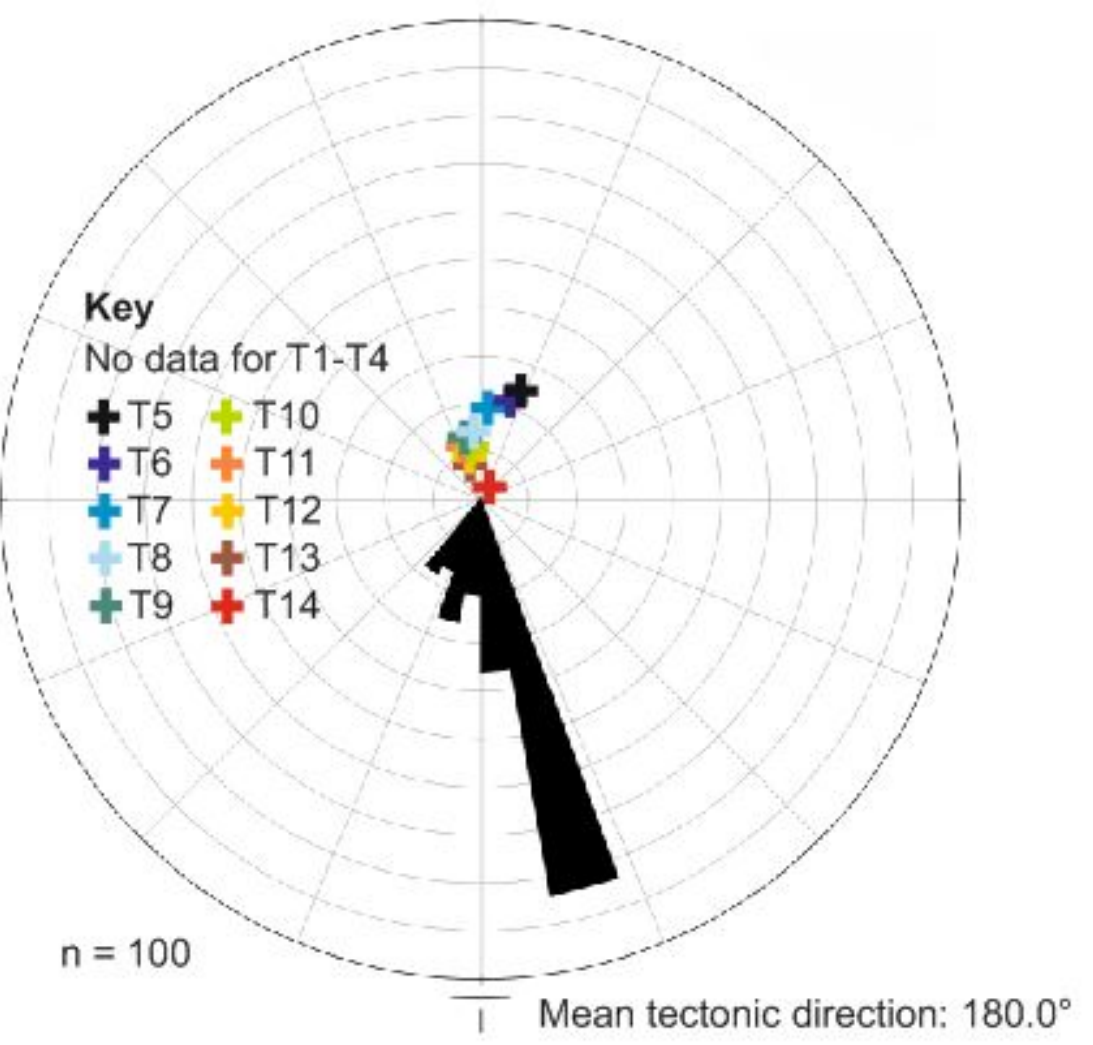


1a. Middle-Pleistocene: Advancing ice
over-pressurises groundwater within $A G F$ sheet sand

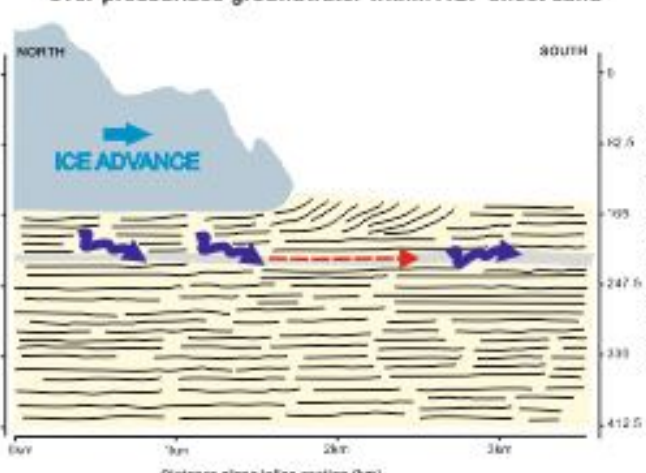

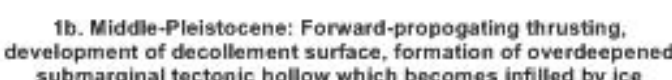

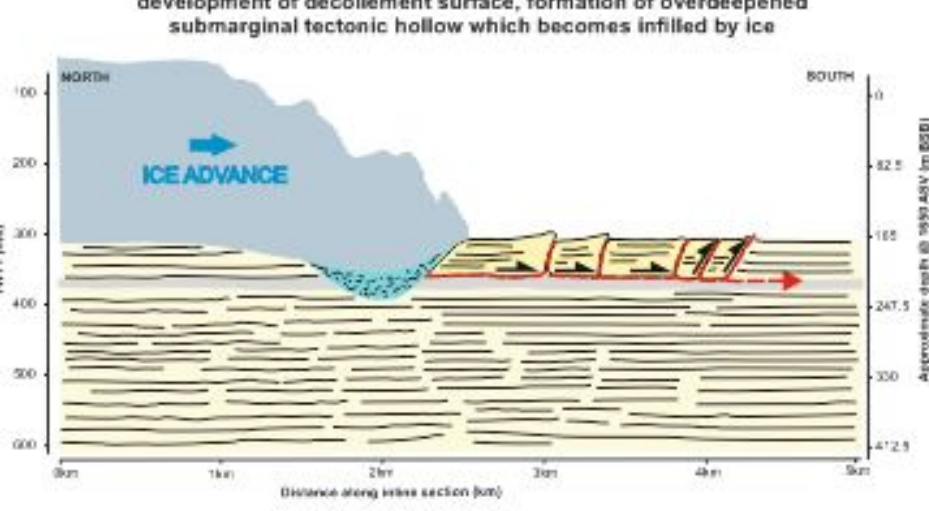

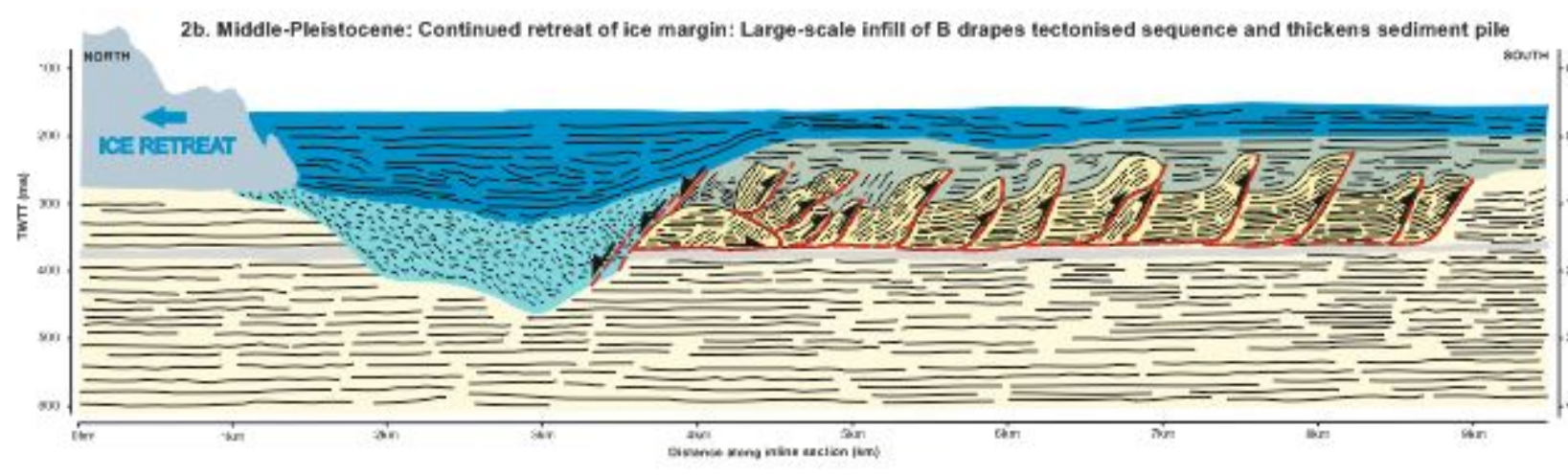

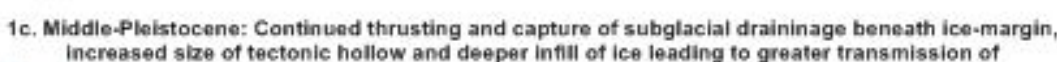
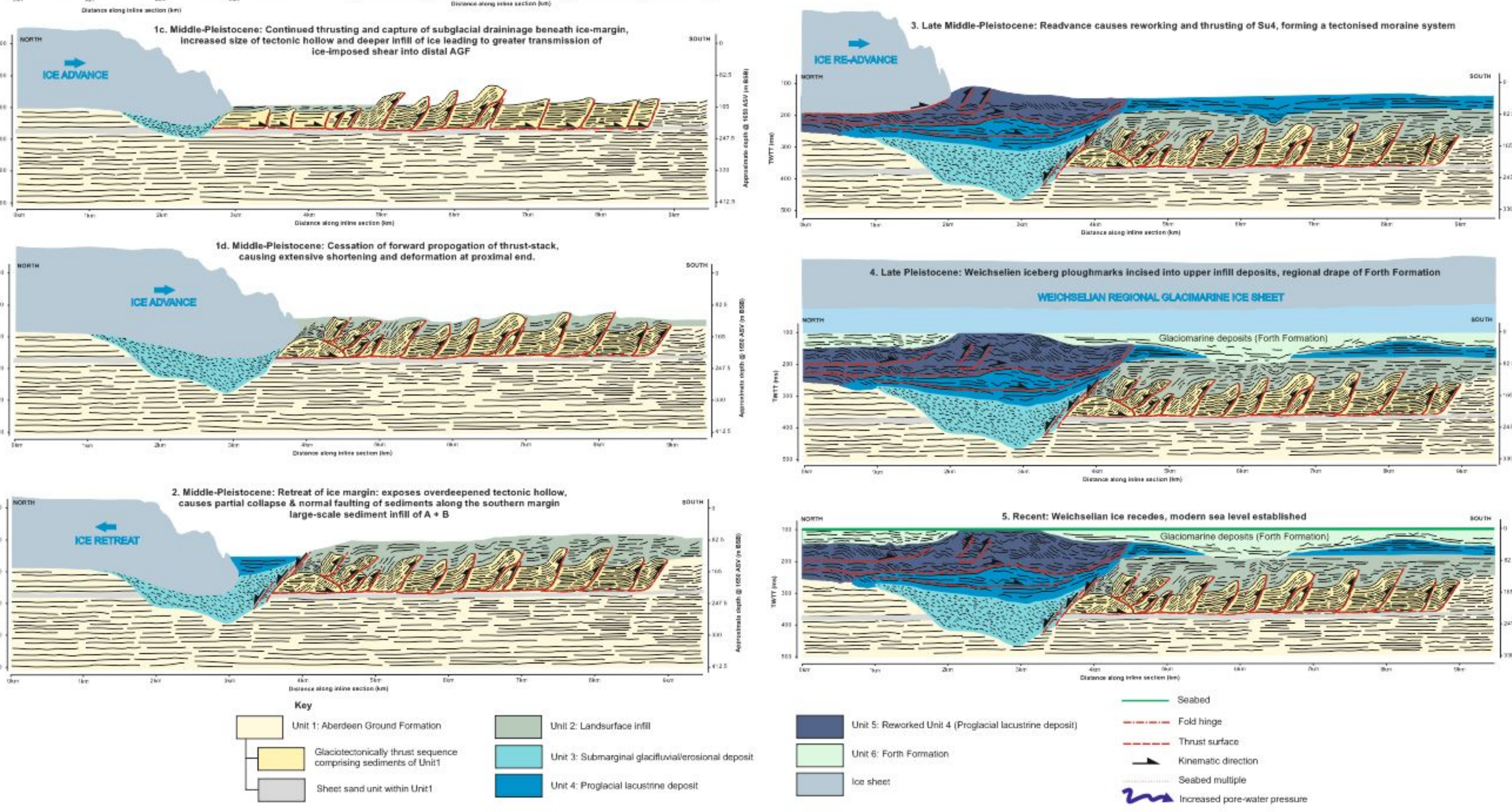


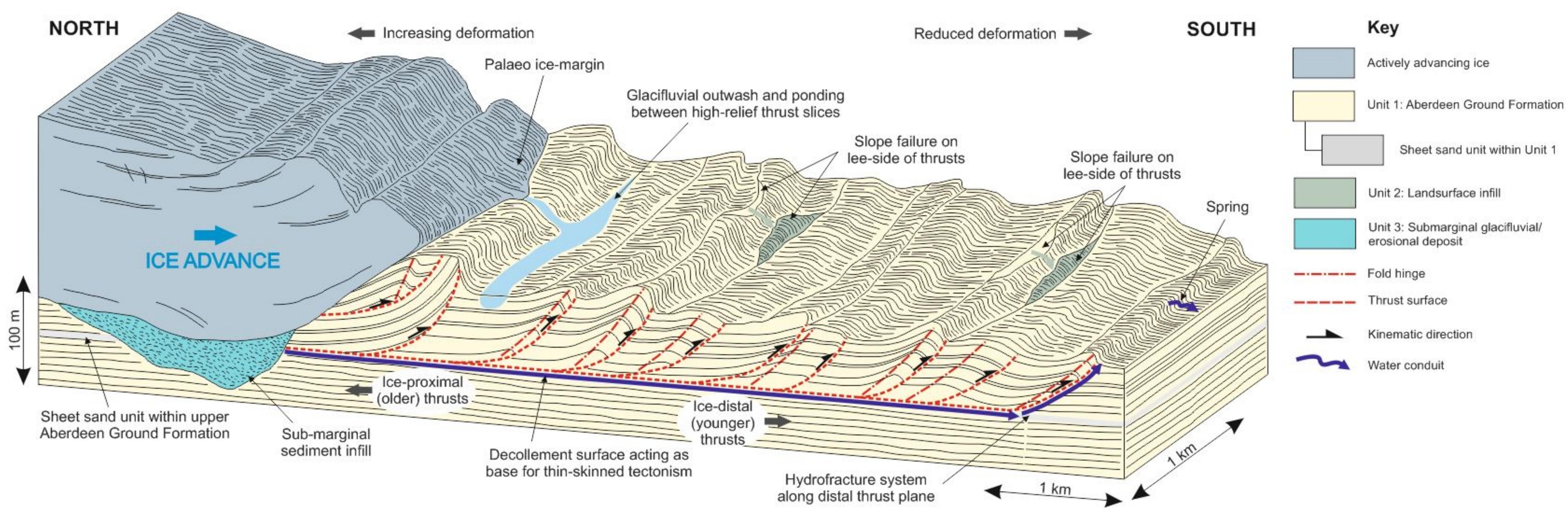

